\title{
Puşkin'in sanatsal yetkinliklere ilişkin görüşleri üzerine bir inceleme
}

\begin{abstract}
Özet
Aleksandr Sergeyeviç Puşkin (1799-1837), hem Rus hem de dünya edebiyatında gerçekçilik akımının öncüleri arasında yer almaktadır. Edebiyatın çeşitli dallarında eserler veren Puşkin'in şair yönü çok daha ön plana çıkmaktadır. Bu çalışmada ise roman, öykü, şiir ve masal türü eserleri incelemeye konu edilmiştir. Puşkin, şiir yazma yeteneği de dâhil olmak üzere, birçok sanat dalında eser verme yetkinliğine ilişkin görüşlerini ifade etmekten geri durmamıştır. Nitel araştırma yöntemlerinden feonomenolojik yaklaşımının benimsendiği bu çalışmada, Puşkin'in sezgiye, gözleme ya da başka türlü algılayış biçimlerine dayalı olarak ortaya koyduğu görüşleri, teorik destekli izahlara dönüştürülmeye gayret edilmiştir. Puşkin'in bakış açısına göre, bireye özgü sanatsal yetkinliklerin temelinde hangi unsurların yer almakta olduğu hususu açıklanmaya çalışılmıştır. Çevresel faktörler olarak, ülkesinin içinde bulunduğu koşulların yanı sıra, Puşkin'in iç dünyasına yansıyan kişisel faktörler de göz önünde bulundurularak yapılan çıkarsamalar, bu çalışmanın başlıca bulgularını teşkil etmektedir.
\end{abstract}

Anahtar Kelimeler: Sanat, Yazınsal Yetkinlik, Puşkin.

\section{An investigation on Puşkin's views on artistic talents}

\begin{abstract}
Alexander Sergeyevich Pushkin (1799-1837) is among the pioneers of the realism movement in both Russian and world literature. The poet side of Pushkin, who works in various branches of literature, is much more prominent. In this study, works of novel, short story, poem and fairy tale were examined. Pushkin did not hesitate to express his views on his competence to produce in many branches of art, including his ability to write poetry. In this study, in which the pheonomenological approach, one of the qualitative research methods, was adopted, Pushkin's views based on intuition, observation or other perception styles were tried to be transformed into theoretical explanations. According to Pushkin's point of view, it is tried to explain which elements are at the basis of individual artistic competencies. The main findings of this study are the inferences made by considering the environmental factors, the conditions of his country, as well as the personal factors reflected in Pushkin's inner world.
\end{abstract}

Keywords: Art, Literary Abilities, Pushkin.

\section{Giriş}

Sanatsal eserlerin, insanların üzerinde yücelik duygusunu oluşturabilmesi için sanatçılar tarafindan büyük bir yetkinlikle bezenmesi gerekmektedir. Tam da bu noktada hem sanatsal ürünlerin üstün nitelikleri hem de sanatçıların sahip olması gereken sanatsal yetkinlikler ön plana çıkmaktadır. Aşağıdaki anlatımlar, sanatsal yetkinlikler hususunda fikir öne süren düşünürlerin görüşlerine yer vererek konuya felsefi temelli bir giriş yapılmasını amaçlamaktadır.

Aristoteles'e (2019, s. 22) göre, sanatçı ile icra ettiği sanat arasındaki birliktelik nedeniyle biri işlemekte, öteki ise işlenmekte; biri devinmekte, öteki de devindirmektedir. Sanat, flütün içine kendiliğinden girmemekte, uyum, karşıtların kaynaşması ve birleşmesiyle ortaya çıkmaktadır. Dolayısıyla; sanatın, araçları, ruhun ise bedeni yetkinlikle kullanması gerekmektedir.

\footnotetext{
${ }^{1}$ Prof. Dr., Anadolu Üniversitesi İşletme Fakültesi, ugurkeskin@ anadolu.edu.tr.
} 
Phyrrhon'un görüşlerini aktaran Romalı düşünür Empiricus'a göre, kuşkucu yaklaşımla bakıldığında; yetkinliği, pratik uygulamaları ve sınırlı bir bilgi alanını belirlemeyi amaçlayan her türlü sanatsal çabanın, ağır bir biçimde eleştirilerek mahkûm edilmesi gerekmektedir. Kuşkucu bakış açısı, her türlü sanatsal yetkinliği, ancak ve ancak tartışmasız bilgi olma iddiası taşımamaları durumunda kabul edilebilir bir biçimde karşılamaktadır (Levy, 2016, s. 68-72).

Lessing, sanatsal eserlerin, yeni bakış açıları geliştirmesi gerektiği görüşü doğrultusunda eserler vermiştir. Romantizmin egemen olduğu on sekizinci yüzyılda Lessing (2020, s. 74; 91), sanatsal yetkinliklerle yapılanmış ve ciddi içerikli eserler kaleme almıştır. Lessing (2019), sanatsal yetkinliklerin temel ayırt edici yönlerini ön plana çıkaran ve eleştirel yaklaşımıyla, kendisinden sonra gelen düşünürleri de etkilemiştir.

İlk bakışta, teorik bir yön içermediği kanaati uyandıran sanatsal çalışmalara, teorik bir anlayışla yaklaşmak pekâlâ mümkün olabilmektedir. Bu husus, sanat felsefecisi Collingwood (2019, s. 12-13) tarafından şu şekilde ifade edilmektedir: "Her etkinlik alanında teorik bir unsur vardır; zihin bu unsur sayesinde bir şeyin farkına varır. Bir de zihnin bunun sayesinde kendinde ve kendi dünyasında bir değişiklik yaptığı uygulamaya yönelik bir unsur vardır... Sanat, uygulamaya yöneliktir; zira sanatta zihin kendisini ve aynı zamanda dünyasını da belirli bir duruma getirmek için bir ideali gerçekleştirmeye çalışmaktadır... Dolayısıyla sanatta zihnin etkinliği ne faydacı ne de ahlaki bir etkinliktir.”

Filozoflar, kendi gerçekliğini ifade ettikleri düşünce düzlemini oluşturarak, kişisel değerlendirmelerini bu bağlamda dile getirmektedirler. Felsefi yaklaşımlarının sonsal amacı, bütünsel gerçekliğin, çerçevesi belirlenmiş bir biçimde yapılandırılması olduğu için, sınırlı bir konuda bile her bir filozof, farklı bir dizi görüş öne sürebilmektedir. Yukarıdaki görüş farklılıkları da filozofların, kişisel anlayışlarını ifade etme çeşitliliğinden kaynaklanmaktadır. Filozofların henüz yaşamakta olduğu yıllarda eserler veren ve geçmiş dönem şair ve düşünürlerinden (kaçınılmaz olarak) etkilenimler taşıyan Puşkin de kendi kişisel (gerçeklik/hakikat) anlayışını biçimlendirmiş ve eserlerini bu anlayış doğrultusunda kaleme almıştır. Bu makale de Puşkin'in eserlerini, sanatsal yetkinliğe ilişkin görüşlerini ön plana çıkaracak bir biçimde yapılandırılmıştır.

\section{1. Çalışmanın yöntem ve sınırlııkları}

\subsection{Yöntem}

Anlatıya dayalı çalışmalara, duyuşsal yönden güçlü yönlere sahip olunmak istendiğinde başvurulmaktadır. Bu sayede, araştırmaya/incelemeye konu edilen olgular, mümkün olduğu ölçüde zenginleştirilerek daha güçlü k1lınabilmektedir (Gürbüz ve Şahin, 2018, s. 112). Doküman/içerik incelemesine dayalı bu makale, anlatı (narrative) ekseninde yürütülmüş olan bu makale, fenomenolojik anlayış doğrultusunda yapılandırılmıştır. Tekil birey düzeyinde yürütüldüğünde fenomenolojik çalışma, belirli bir kişinin herhangi bir fenomen ya da kavramla ilgili görüş, yaklaşım ya da deneyimlerinden çıkarsanabilecek ortak anlamları ifade etmektedir. Fenomenolojinin başlıca amacı, belirlenen bir fenomene ilişkin bireysel deneyimleri, evrensel nitelikteki açıklamalara dönüştürmek olarak ifade edilmektedir (Creswell, 2016, s. 77). Buna karş1lık fenomenoloji, salt betimleme değil, anlamlandırmaya dönük araştırmacı deneyim ve yorumunun da işe koşulduğu bir çalışma biçimini ifade etmektedir. Bu sayede araştırmacı, derinlemesine bir düşünsel düzleme yönlenebilmekte ve araştırmasıyla sağlıklı bir etkileşim oluşturarak fenomenle ilgili etkili betimlemelerde bulunabilmektedir (Manen, 1990, aktaran Creswell, 2016, s. 80). İfade edilen özelliklerden yola çıkılarak bu makale, fenomenoloji biçimlerinden yorumlayıcı fenomenoloji anlayışı ekseninde desenlenmiştir. Fenomenolojinin kurucusu olarak kabul edilen Husserl (2017, s. 48), bu yöntemi şu sözlerle ifade etmektedir: "Fenomenoloji; görerek, aydınlatarak, anlam belirleyerek ve anlam ayrımı yaparak yol alır. Fenomenoloji karşılaştırır, ayrım yapar, bağlar, ilişkiye sokar, parçalara böler, öğelerine ayırır, ama her şeyi saf görmeyle yapar. Kuramlaştırmaz, matematikleştirmez.”

Husserl'a (2020, s. 88) göre, en eski kaynaklara yönelen felsefi eserler ile çağdaş bilimsel çalışmalar aracıllğıyla tam anlamıyla bir fenomenolojik özkavramasına ulaşmak mümkün olabilmektedir. Bu sayede; dolaylı, sembolleştiren ve matematikleştiren yöntemlere başvurmaksızın sağlıkı bilgilere/kazanımlara ulaşılabilmektedir. Husserl'ın bu görüşleri aslında, "gerçek tekillik, aynı zamanda kendi içinde evrenselliktir" diyen Hegel'in (2011, s. 20) yaklaşımından çok da farklı bir anlayış ortaya koymamaktadır. 
Betimleyici yönü ön plana çıkan fenomenolojide, açılanacak, dedüktif olarak çıkarım yapılacak hususlar gündeme getirilmemektedir. Bir öz betimlemesi olarak düşünülmesi gereken fenomenoloji, özleri kavrarken, onlardaki temel bağlılıkları da kavramaktadır (Mengüşoğlu, 2020, s. 13). Fenomenolojik tavrın yöneldiği alan, doğal tavrın yöneldiği alan gibi hazır bir biçimde araştırmacının karşısına çıkmamaktadır. Bu alanın elde edilmesi gerekmektedir. Bunun için fenomenolojik redüksiyona (ayıklama) yönelme zorunluluğu bulunmaktadır (Husserl, 2020, s. 86-87). Özellikle sanatsal eserleri tümdengelimci bir biçimde izah etme çabası hem zorlu bir çaba hem de ele alınan sanatçıyı ve sanatını, apriori yaklaşımların içeriğine hapsetme sakıncasını doğurmaktadır. Özgün değerlendirmelere dayalı yorumsamacı anlayış, fenomenolojik yönteme daha uygun olduğu için bu makale tabiatıyla, yorum eksenli olma mükellefiyeti taşımaktadır.

Kendi metodik çerçevesi içinde kalmak koşuluyla, fenomenolojik çalışmalardaki yoruma dayalı yazarlığın ön adımı olan okuma sürecini Novalis (2003, s. 16-17) şu sözlerle ifade etmektedir: "Okuyucu, vurguyu keyfi olarak yapar; esasen bir kitaptan ne isterse onu okur. Alış1lmış anlamda her yerde geçerli olan okuma şekli yoktur. Okumak serbest bir eylemdir. Neyi nasıl okumam gerektiğini kimse bana söyleyemez."

\subsection{Sinirlıliklar}

Ahlak ve yaşam biliminde edinilecek kesinlik derecesi her ne ise, sanatsal yetkinliklere konu olan uğraşıların ve ortaya çıkan eserlerin değerlendirilmesinde erişilebilecek kesinlik derecesi de aynı olmaktadır (Burke, 2008, s. 27). Burke'e göre, bağımsız bir estetik alandan bahsetmek, aynı zamanda zorunlu olarak güç/iktidar, cinsiyet, ahlaki duyarlılık, gelenek ve sosyal hiyerarşiden bahsetmek anlamına gelmektedir (White, 2013, s. 9). Bu yönüyle bakıldığında Burke'ün söz konusu yaklaşımının, sosyal dünyadaki bütün olgulara güç/politika örüntüsüyle yaklaşan Foucault’nun görüşlerini öncelediği rahatlıkla görülebilmektedir. Foucault'nun, bütün toplumsal ilişkilere güç/politika örüntüsüyle yaklaştığı hususu, bu alanda ortalama bir bilgi düzeyine sahip birisi için (genel kültür düzeyinde bile olsa), bilinen bir husustur. Bu nedenle Foucault'nun birincil kaynaklarına ayrıca başvurma lüzumu burada söz konusu olmamaktadır. Kaldı ki, yukarıdaki anlatımların ötesine geçerek, görece çağdaş bir yazar olan Foucault'nun görüşlerinin arka planındaki Burke temellendirmesi, ayrı bir çözümlemeyi gerektirmektedir.

Sanatın çeşitli alanlarında eser veren sanatçılar, teorik bilgiye gereksinim duymaksızın başarılı olabilmektedirler. Bu nedenle sanat deneyimi derin olan kişiler tarafından yazılan süreli ya da süresiz yayınlar, genellikle felsefi/bilimsel düşünce eğitimi eksikliğinden dolayı başarısız olmaktadır (Collingwood, 2019, s. 109). Oysa anlaşılması zor gibi görünen bilme ya da yapma biçimleri, ancak ve ancak belirli bir teorinin kapsamına girdiğinde tam anlamıyla izaha kavuşabilmektedir (Gasset, 2018, s. 15). Dolayısıyla bu durum, teoride yetersiz oldukları hâlde pratikte yetkin olan sanatsal ürünlerin sahip bulunduğu niteliği açıklamakta, teori bilmese de kendi sanatında başarılı sanatçıların başlıca özelliğini ifade etmektedir.

Ele alınan kavramların sınırlarını genişletmek yerine, inceleme/araştırma öğesine yalnızca sınırlı ve kısmi bir bakışla yaklaşmak gerekmektedir. Dolayısıyla, yapılacak olan bilimsel incelemelerin sınırlarını, başlangıçta hükmüne uyulan belirleyici ve çerçeveleyici ilkeler belirlemektedir (Burke, 2008, s. 16). Bu makalede de söz konusu anlayış doğrultusunda yapılandırılmış ve sınırlandırılmıştır. Makaleye ilişkin bir diğer sınırlılık, Puşkin'in bütün eserlerinin Türkçe çevirisinin yapılmamış olmasından ileri gelmektedir. Zira bu makale, Puşkin'in Türkçe çevirisi yapılan eserleri ile sınırlanmıştır. Erişilebilen söz konusu birincil kaynaklar, makaledeki analizler açısından yeterli ölçüde veri doygunluğunu sağladığı için, Türkçe çevirisi olmayan eserler, inceleme kapsamının dışında tutulmuştur.

\section{Teorik arka plan}

\subsection{Yetkinlik kavramının sanatsal boyutu}

"Yetkin" kavram1, Türkçe Sözlük'te (2011, s. 2586) "gerekli olgunluğa erişmiş, olgun, kâmil" ifadeleriyle tanımlanmaktadır. Türk Dil Kurumu Yayınları'nın aynı kaynağında (2011, s. 2583) yakın anlamlı sayılabilecek "yetenek" kavramı ise kabiliyet, istidat, kapasite ifadeleriyle açıklanmaktadır. Yetenek kavramını açıklamak için başvurulan "kabiliyet" ve doğuştan gelen yetenek anlamındaki 
“istidat” sözcükleri, bir insanın özellikle sanatsal alanda sahip bulunduğu ve eserler verdiği sanat alanı için haiz olması gereken meziyetleri bütünüyle dile getirememektedir. Zira nitelikli sanatsal ürünler; salt kabiliyet/kapasite ya da doğal becerilerle ortaya çıkmamakta; incelikli/derinlikli bir çalışma ve gayretin bileşimiyle vücuda gelebilmektedir. Böylesi bir emek ve gayret ise ilgili sanat alanında olgunluğu, mütekâmil olmayı, bir diğer deyişle yetkinliğe erişmiş bulunmayı gerekli kılmaktadır. Söz konusu nedenlerden dolayı bu makalede, daha kapsayıcı ve kuşatıcı bir kavram olması bakımından "yetkinlik" kavramına sadık kalınmıştır.

Yetkinlik kavramı, hem bireysel hem de topluluk bağlamında ifade edilebilen bir kavram olma niteliği taşımaktadır. Zira örgütlü iş yapma birimlerinin (kurum/kuruluş/işletmelerin) sahip bulunduğu yetkinlikler (core competence), rakiplerinin sahip olmadığ 1 özel yeterlilik, kaynak ve temel rekabet üstünlüklerini ifade etmektedir (Hamel ve Prahalad, 1996, s. 220). Bireysel düzeyde sahip bulunulan yetkinlik kavramı ise örgütsel yetkinliklerden farklılık göstermesine karşın, yukarıdaki açıklamaya benzer biçimde, kişiye özgü ve diğer insanların sahip olmadığı yeterlilik ve üstünlükleri ifade etmektedir.

Barney, belirli bir grup bireyin sahip olduğu yetkinlik düzeyini daha ayrıntılı bir biçimde ifade edebilme bağlamında VRIN analizini formüle etmiştir. Barney'e göre, herhangi bir yeteneğin, yetkinlik olup olmadığ 1 ; value (değer), rareness (nadirlik), imitability (taklit edilebilirlik) ve nonsuitable (ikame edilemezlik) kelimelerinin baş harflerinden yola çıkılarak yapılan çözümlemeyle belirlenebilmektedir. Organizasyonel çapta veya belirli bir çalışma grubu için öngörülen bu temel bakış açısını bireysel yetkinliğe uyarlayabilmek mümkün gözükmektedir. Nitekim Barney için öncül görüş teşkil eden Cahiz (2019, s. 52) şunları ifade etmektedir: "Neredeyse her insanda eksiklikler vardır. Kemal derecesine ulaşan çok az insan mevcuttur." Bruno (2020, s. 83), çokluğun içinden saygın ve değerli bir şeyin çıkmayacağı, yetkin ve değerli şeylerin, her zaman az sayıda (nadir) olanların arasından çıkacağını belirtmektedir. Adam Smith ise oyuncu, şarkıcı ve dansçıların, nadir ve güzel yetenekleri sayesinde astronomik kazançlar elde edebildiklerini öne sürmektedir (Butler, 2018, s. 36-37). Sıralanan bu görüşlerden hareketle, Barney'in, yüzyıllar öncesine dayanan bir anlayışı, çağdaş biçimde yorumlayarak yeniden ortaya koyduğu anlaşılmaktadır. Zira hangi tarihsel dönemde olursa olsun yetkinlik denildiğinde insan aklında benzer hususları çağrıştırmaktadır. Sonuç olarak Barney, yukarıda sıralanan düşünürlerle benzer bir noktadan yola çıkmış fakat söz konusu ortak görüşü ileri bir düzeye taşıyarak yetkinliğe ilişkin daha ayrıntılı bir analiz aracı ortaya koymuştur.

Her sanatçının kendisine özgü yetkinlikleri bulunmaktadır. Belirleyici nitelik taşıyan, bir diğer söyleyişle ön plana çıkacak olan husus, sanatçının kendisine has altyapı ve yetkinlikleridir. Temel (öz, çekirdek) yetkinlikler (yetenekler, beceriler), sanatçıyı, diğerlerinden ayıran, sanatsal üretimini gerçekleştirmede başlıca rol oynayan, taklit veya ikame edilemeyen, belirgin bir değer ifade eden yeterlilik, beceri ve yetkinlikleridir. Yetkinlikleri sayesinde sanatçılar, toplumsal ve kültürel yaşama artı değer katabilmektedirler. On dokuzuncu yüzyıl düşünürlerinden Novalis (2003, s. 35), bu konuda şunları ifade etmektedir: "Bir toplum, üstünlüğü sadece edebiyat ve sanat eserleri yoluyla elde edebilir, başka türlü ondan nasıl bir bireysellik, ayırt edici özellik arta kalır ki? ... İnsan, erginleşmeden ve kendi öz varlığını göstermeden tarihsellik kazanabilir mi?"

Yetkinlik, organize olmuş bir grup insanı, diğerlerinden üstün kılacak olan kaynak ve kabiliyetleri vurguladığına göre, benzer bir vurgulamayı, tekil birey düzeyinde de ifade etmek pekâlâ mümkün olabilmektedir. Özgün bir değere sahip bulunan, taklit edilmesinin zor olması yönüyle de ender/nadir nitelikli eserler, sanatsal yetkinliğe işaret etmektedir. Bu yetkinlik sayesinde büyük sanatçıların eserleri, kolaylıkla diğerlerinden ya da taklitlerinden ayıt edilebilmektedir. Dolayısıyla da yetkinliklerle donatılmış sanat eserlerinin taklit edilmesi neredeyse olanaksız hâle gelmektedir.

\subsection{Sanatsal yetkinliği açıklayan başlıca yaklaşımlar}

Puşkin, şiirin yanı sıra diğer anlatı türlerinde de eserler verdiği için bu makalede, "anlatı yetkinlikleri” bağlamında öne sürdüğü görüşlere yer verilmektedir. Zira şiir/nazım dilinden düzyazı/nesir diline geçiş döneminde yaşamış olan Puşkin'in makalede ele alınan görüşleri, hem şiiri hem de düz yazıyı niteleyebildiği için bu çalışmada "sanatsal yetkinlikler" ifadesi tercih edilmiştir. Sanatsal yetkinliğe ilişkin temel bakış açılarını aktarmaya yönelik görüşlere aşağıda sırasıyla yer verilmiştir. 
Sanatsal yetkinliğin doğuştan ya da esinlenmeyle edinildiğini öne süren görüşler: Kendisinden önceki filozofların sanatsal yetkinliğe dair görüşlerini özetleyen Gazzali’ye (2020, s. 180-181) göre birey, bilme ve yapma gücüyle donatılmış bulunmaktadır. Yapma gücü, bireyin bedenini insana özgü düşünceden üretilen ve sanatlara yönelmiş biçimde hareket ettiren bir ilke olma özelliği taşımaktadır. Bu gücün, bedenin diğer güçlerine egemen olması, diğer güçlerin bu sayede eğitilmeleri ve ona boyun eğmeleri gerekmektedir.

Gazzali'nin çağdaşı olan, belagat ve şiir sanatının yaygın olduğu Basra'da yetişen Hariri (2012) de Makamat adlı eserinde edebi sanatlardaki yetkinliğin doğuştan geldiğini vurgulamaktadır. Elli adet kısa hikâyeden oluşan bu eser, kelime sanatlarıyla yüklü, Zeyd ve Hemmam adlı kahramanlar ekseninde kaleme alınmıştır. Anlatım kahramanları, kelime sanatlarını doğaçlama (irticalen) bir biçimde dile getirerek yetkinliklerini ortaya koymaktadırlar.

İtalyan düşünür Bruno (2020, s. 65-66) sanatsal bir olguya giriş yapmak söz konusu olduğunda sanat tanrıçalarına, esin vermeleri için yakarışta bulunmak gerektiğini belirtmektedir. Bu anlayış doğrultusunda Bruno, içinin, sanat tanrıçalarının soluğuyla dolmasını (esinlenmeyi) dilemektedir. Bruno, dileğinin yerine gelmesi sayesinde aklının geliştirdiği tüm düşüncelerin konularının ve ruhunun kabul ettiği tüm duyguların daha üstün bir duruma geleceğini ifade ederek, yukarıda vurguladığı gerekliliği yerine getirme çabasına yönelmektedir.

Bir diğer İtalyan düşünür Vico (2017, s. 20), hayal gücü ve hafızanın egemen olduğu resim, şiir, belagat gibi güzel sanatlara karşı gençlerin doğal bir ilgi duyduklarını belirtmekte ve bu ilginin köreltilmemesi gerektiğini vurgulamaktadır. Vico (2017, s. 47), Allah vergisi olarak nitelendirdiği sanatsal yetkinlik ve dehanın, kültür araştırmalarıyla da zenginleștirilmesi hususunu vurgulamakta, farklı disiplinlerin her bir çiçeğinden bal almayı bilme gerekliliğini dile getirmektedir. On sekizinci yüzyıl düşünürü Mettrie (1985, s. 38) ise sanatsal eğilimin doğadan geldiğini belirtmekte ve şunları ifade etmektedir: "Sadece onun sayesinde değerli niteliklere sahip oluruz, her şeyimizi ona borçluyuz. Bu nedenle niçin doğal yeteneklere sahip olan insanlara, borç alınmış gibi sonradan edinilmiş erdemlerle parlayan insanlara verdiğim kadar değer vermeyeyim?"

İngiliz düşünür John Stuart Mill’e göre bir sanatçı olarak şairin en önemli ilişkisi, okurlarıyla değil, "esin perisiyle" olan ilişkisidir. Esin perisi kötü bir işverendir. Şaire esin verir ("kutsal nefesini" esirgemez) ama hiç para vermez. Bu nedenle şair olanlar yoksulluğu göze almaktadırlar (Sutherland, 2018, s. 198). Balzac (2020, s. 49-53), paha biçilmez sanatsal yetkinlikler sayesinde, yeryüzü üstündeki her şeyin üstüne yazılmış tanrısal sözün yorumlanabilmekte olduğunu ifade etmektedir. Balzac'a göre, sanatların duygusuyla yaşayan bazı insanların bu yetkinlikleri, içlerine attıkları duygular sayesinde özgün bir dehaya dönüşmektedir.

Sanatsal yetkinliğin çalışarak edinildiğini öne süren görüşler: Milattan önce birinci yüzyılda yaşayan Romalı şair Horatius (2019, s. 7), kişisel yetkinliğe uygun konu seçilmesi durumunda anlatı sanatlarında başarı elde edilebileceğini vurgulamaktadır. Horatius (2019, s. 22; 24; 33), başta şiir olmak üzere, genel olarak bütün edebi uğraşılarda sanata, becerinin eşlik etmesi gerektiğini, bunun da uzun ve zahmetli bir eğitimi gerektirdiğini vurgulamaktadır.

Dokuzuncu yüzy1l düşünürü Cahiz’e (2019, s. 81-82) göre, her ne kadar kemale ulaşmak zor olsa da yine de ona erişmek imkân dâhilindedir. Yetkin insanın ulaşabileceği sınır öyle bir noktadır ki bu noktaya ulaşabilenler çok nadirdir. Ancak kişinin azmi doğru olursa, gayretin de hakkını verirse o sınıra ulaşmayı hak etmekte ve yücelmek istediği hedefe kavuşabilmektedir. Kişinin, bakışını daha üst noktalara çevirmesi gerektiğini vurgulayan Cahiz (2019, s. 83-84), anlatı sanatlarında yetkinlik kazanabilmek için dil ve belagat kitaplarını okuyarak terennüm edilmesi, fesahat ve hitabetle süslenilmesi, sürekli ilim ve hikmet meclislerinde bulunulması gerektiğini ifade etmektedir. Cahiz (2020: 69), poetik alanda yetkinlik elde edilebilmek için çalışmayı ve zorlu uğraşıların üstesinden gelme gerekliliğini aşağıdaki uzun cümlesiyle açıklamaktadır:

Şiir söyleyenler, seci yapmak için kendilerini zorlayanlar, ikili beyitlerden (el-müzdevic) oluşan kasideler derleyenler, nesir yazımında ustalık kazanmış olanlar, eğer bir de anlamların derinliklerine vakıf, ölçüleri tam koyma konusunda becerikli iseler, yazdıkları şeyler insan doğası tarafından hoş karşılanıyor, zihinler bunu kolaylıkla hazmediyorsa, sözcükleri ve hece sayısı az ise bu tür sözler rekabet halinde ve büyük çabalar harcayıp sıkıntılara katlanarak ortaya çıkanların 
sözlerinden daha çok övgüyü hak ederler, kalplerde daha güzel bir konuma yerleşirler ve dinleyenlere daha çok fayda sağlarlar.

Gasset'e (2018, s. 26) göre sanatsal yetkinliğe sahip olmak yalnız başına yeterli olmamakta, sanatsal eser ortaya koymaya dönük yoğun bir ilgi hasretmeye ihtiyaç duyulmaktadır. Ona göre, harikulade bir sanat eserinin sırrı, bazı bilim insanları gibi kendini entelektüel istilaya teslim etmemeye dayanmaktadır. Bu konuda Gasset (2018, s. 36) şu görüşleri öne sürmektedir: "Bilim, sanat, adalet, görgü kuralları ve din, şahsımızı açlık veya soğuğun yaptığı gibi, vahşice istila etmeyen gerçeklik yörüngeleridir; yalnızca onlara karş1 istek duyanlar için var olurlar." Gasset'e göre, antikçağ poetikasında şairin, eserini oluştururken uyması gerektiği kurallar belirleyici olmuştur. İlham perilerinin, uysal birer arı gibi ballarını yaptıkları boş şemaların, biçimsel yapılar olduğu görüşü ön plana çıkarılmıştır (Gasset, 2018, s. 66). Antik çağ için geçerli olduğu ifade edilen söz konusu yetkinlik, gönümüze geldiğinde belirli ölçülerdeki anlayış değişikliklerini de beraberinde getirmiştir. Daha sonraki dönemlerde, bu görüş giderek gerilemeye başlamış ve sanatçılar çoğunlukla katı biçimsellik anlayışının karşısında yer almaya başlamıştır.

Tolstoy, konuya çok da olumlu sayılamayacak bir biçimde yaklaşmakta ve sanatsal yetkinliği "uydurmac1l1k" olarak nitelendirmektedir. Tolstoy, bu konudaki görüşlerini şu şekilde ifade etmektedir (Gorki, 2020, s. 57-58): "Sanatın bir yalan, herkesin kendince uyguladığı bir yapmacık, insanlara zararlı bir şey olduğunu söylemem bundan dolayı. İnsan gerçek yaşamın ne olduğunu değil, yaşam konusundaki kendi kanısını yazıyor düpedüz. Benim bir kuleyi ya da denizi, ya da Tatar'1 nasıl gördüğümden kime ne, ilginç bir yanı, bir yararı var mı bunun?"

Habermas'a (2019, s. 47) göre, özellikle son y1llarda amaca yönelimli rasyonel eylemlerin öğrenilmiş birtakım kuralları, becerilerin disiplinine yöneltmektedir. Edinilen beceriler, karşılaşılan güçlükleri ya da problemleri gidermeye yetkin kılmakta, bu yetkinlik ise kişisel düzeyde özgün (örneğin sanatsal) ürünler ortaya çıkarılmasına katkı sağlamaktadır.

Sanatsal yetkinliğin iki yönünü de vurgulayan görüşler: On birinci yüzyıl düşünürü Tevhidi (2020, s. 18), insanın, yetkinliğe erişebilecek niteliklere sahip bir yaratılışa sahip olduğunu belirtmektedir. Tevhidi'ye göre, şerefli amaçlar doğrultusunda, yüksek dereceleri elde edebilecek şekilde planlanıp programlanmış donanımları bulunan insan, Kur'an-1 Kerim'in Tin Suresi'nin dördüncü ayetindeki "ahsen-i takvim" (en güzel kıvam) yüce beyanın, insanın yaradılış niteliğini açıkladığını vurgulamaktadır. Tevhidi (2020, s. 94-95), ruhun düşünme/konuşma ile ilgili bölümü sayesinde erişilebilen yetkinliğin, yalnızca doğuştan gelen özelliklerle değil, azimli çalışmayı da gerekli kıldığgını belirtmektedir.

On ikinci yüzyıl düşünürü Razi’ye (2018, s. 30) göre bazı bireyler asli fitratlarının bir gereği olarak yücelik makamını arzulayacak yaratılışa sahip bulunmaktadır. İlahi esintilerin süreklilik arz ettiğini ve nasibi olan herkes ona ulaşabileceğini ifade eden Razi, Ankebut suresinden (29/69) "Bizim uğrumuzda çaba sarf edenleri yollarımıza ulaştıracağız" ilahi hükmünü, bu görüşüne delil olarak göstermektedir. Razi, yetkinliğe ilişkin iki yönlü yaklaşımını şu şekilde ifade etmektedir: "Bir kısım nefisler, amaç için güçlü bir istidada sahip olurken bir kısım nefisler de bunun için hiçbir istidada sahip olmayabilir. Bu iki taraf yani yetkinlik ve yoksunluk tarafları arasında güçlülük ve zayıflık bakımından muhtelif ara durumlar vardır."

\subsection{Puşkin'in yaşamı ve eserlerine ilişskin genel bilgiler}

Puşkin, Rus tarihinin en ünlü şairi, yazarı ve yeni Rus edebiyat dilinin kurucusu olarak kabul edilmektedir (Miziev ve Necdet, 2003, s. v). Soylu bir sınıftan gelmesine karşın, genç yaşlarından itibaren çiftçi kıyafetlerini giyerek köylerde, şehirlerin yoksul mahallelerinde, pazarlarda ve meydanlarda dolaşarak sıradan Rus insanlarını dinleyen Puşkin, bu sayede halka daha yakın bir yazın biçimi geliştirebilmiştir (Maga, 2003, s. 49). Kullandığı gündelik halk dili, soylu çevrelerce ağır bir biçimde eleştirilen Puşkin, gençler tarafindan övgüyle karşılanmıştır. Puşkin, yaşadığı dönemin Rus şiirine bir hayli aykırı gelebilecek yazım biçimleri kullanmıştır (Yükseler, 2017, s. 7).

Puşkin'in, ilk dönem şiirlerinde Parny, Andre Chenier ve özellikle Byron gibi Avrupalı şairleri taklit ettiği eleş̧irisine karşılık olarak Dostoyevski (2019, s. 22-23) şunları ifade etmektedir: "Taklit olan bir şiirde Puşkin'in eserlerinde görülen şahsi istıraplar ve derin anlamlar bulunmaz.” Dostoyevski'nin 
de ifade ettiği üzere Puşkin, erken dönem eserlerinden itibaren büyük bir özgünlük ve yetkinlik ortaya koymaya başlamıştır.

Şiirin gelişim süreci, müzik ile iç içe geçen bir nitelik taşımaktadır. Benzer bir iç içe geçme durumu (bu konuda dünyanın öncülerinden biri olan) Puşkin'in eserlerinde sıklıkla görülebilmektedir. Dolayısıyla, söz konusu durum, şiirsel anlatımdan düzyazıya geçiş sürecinde de, birbirini öncelemekten ziyade, birbirini destekleyici bir şekilde gelişme kaydetmiştir. İfade edilen genel durum, Puşkin özelindeki bir dönüşümü de ortaya çıkarmıştır. Zira Puşkin'in düzyazıya, edebiyatın anlatı türlerine, onun kendi sözleriyle "içine düşen bu yeni cin"e olan ilgisi 1820'lerin ortalarında başlamıştır (Bkz. Puşkin, 2020b, s. 121). Bu ilgi; Yevgeni Onegin ile manzum-roman, Kolomna'daki Küçük Ev ve bir ölçüde de Bronz Atll ile poema türündeki ürünlere dönüşerek, erken dönem düzyazı-anlatı örnekleri olarak edebiyat dünyasına girmiştir. 1830'lu yıllarda ise roman, giderek daha öncü tür olmaya başlamıştır.

Puşkin, derin bir anlayışla dolu bütün sanat eserlerini, kendisinden sonra gelecek yazarlar ve ileride aynı alanda çalışacak olanlar için bir rehber olarak bırakmıştır. Yalnızca Puşkin, kendini tamamen başka bir ülkenin insanları yerine koyabilme yeteneğine sahiptir ve böyle bir yetenek dünyanın başka hiçbir şairinde görülmemiştir (Dostoyevski, 2019, s. 36-39).

\subsection{Literatürdeki çalışmaların özeti}

Dante Alighieri (2020), düzyazı-şiir karışımı Yeni Hayat adlı eserini Puşkin'den beş asır önce kaleme almıştır. Romantizm ve barok başta olmak üzere çeşitli akımların etkili olduğu Dante-Puşkin arası dönemde başka örneklere de rastlanmaktadır. Buna karşılık, "gerçekçi”" yönü başta olmak üzere, Puşkin'in eserlerine hakiki anlamda öncülük teşkil eden eserlere rastlayabilmek olası görünmemektedir. Salt bu yönüyle düşünüldüğünde, Puşkin'in öncülük teşkil eden eserlerini ele almak bile başlı başına özgün bir inceleme/araştırma yapılmasına katkı vermektedir. Puşkin'in eserlerinin özgünlügü, bu makalenin yazılması için elbette ki tek başına yeterli görünmemektedir. Bu nedenle, Puşkin'in eserlerine dönük olarak kaleme alınmış olan bilimsel çalışmaların da gözden geçirilmesi gerekmektedir. Aşağıdaki, özet niteliğindeki literatür aktarımı da söz konusu gereklilikten yola çıkılarak yürütülmüştür.

Yetkinlik konusunda Türkçe ve İngilizce literatürde çok sayıda çalışma yürütülmüş olmasına karşın sanatsal yetkinlik konusunda özellikle Türkçe kaynak sayısı oldukça sınırlıdır. Literatürde Puşkin üzerine yapılan çok sayıda eser olmasına rağmen, yukarıda da ifade edildiği üzere, Puşkin'in sanatsal yetkinliklere ilişkin görüşlerini ele alan çalışmalar oldukça az sayıdadır. Sanatsal yetkinlik özelindeki Türkçe ve İngilizce çalışmaların yanı sıra Puşkin'in konuya ilişkin yaklaşımına katkı sağlayabilecek çalışmalar aşağıda kısaca ele alınmıştır.

Literatürdeki araştırma ve incelemelerin Puşkin'in yalızca masalları, şiirleri ya da hikâyeleri/romanları gibi belirli bir grup eserleri ekseninde yürütüldüğü görülebilmektedir (Bkz. Ersoy, 2010). Bunun yanı sıra, sanatsal yetkinlik kapsamında da görece daha fazla sayıda yabancı kaynağa rastlanırken, yürütülen az da olsa Türkçe çalışmaların, sanatsal yetkinlik arayışının Türkiye ve dünyadaki öncüllerini ele almakta olduğu görülebilmektedir (Bakkal, 1998; Çıkla, 2008; Doğan, 2011). Literatürde ayrıca, sanatsal yetkinliğin biçimsel (Durukoğlu ve Toprak, 2019) boyutu ile psikolojik (kökeni Nietzsche'ye dayanan ve Adler tarafından geliştirilen bireysel psikoloji bağlamında tartışılan ve kişinin yetersizlik duygusu ile kusursuzluk gayretinden kaynaklanan güç istenci eksenli) çalışmaların yer aldığı da görülebilmektedir. Oysa bu makalenin konusu ile doğrudan ilintili geçmiş tarihli çalışmaya rastlanamamakta ve ancak dolaylı yönlerden ilişki kurulabilecek çalışmaların yayınlandığı görülebilmektedir. Dolayısıyla da makalenin, özgün sayılabilecek bir konu-perspektif (subject-aspect) ayrımı ortaya koyduğu yargısı ortaya çıkmaktadır.

\section{Analiz: Puşkin'in eserlerinde sanatsal yetkinliklere ilişskin anlatımların değerlendirilmesi}

Puşkin, şiir çevirisinin özel güçlükleri nedeniyle, kendi ülkesi dışında, şiirlerinden çok öykü ve romanlarıyla tanınmaktadır (Behramoğlu, 2020, s. vii). Bu durum, Puşkin'in edebiyatın şiir dışındaki diğer dallarında da ne denli yetkin olduğunu göstermektedir. Dostoyevski (1973, s. 208 aktaran Behramoğlu, 2013, s. 20) bu konuda şunları ifade etmektedir: “...tıpkı Puşkin'i, Gogol'u anlamadıkları gibi anlamayacaklardır. Bana öyle geliyor ki bizim en büyük yeteneklerimizin hepsi, Avrupa için uzun 
süre bilinmez kalmaya yazgılıdır. Ve hatta şöyle denebilir: Yetenek ne kadar büyük ve kendine özgüyse, o ölçüde bilinmez kalacaktır."

Puşkin, sanatsal açıdan geniş bir çeşitlilik arz eden bir dizi yetkinliğe sahip bulunmaktadır. Birçok alanda da öncü kabul edilen eserler vermiştir (Kuleşov, 2018, s. 161; 197-198). Puşkin, yazdığ1 eserlerde edebi yetkinliklerini ortaya koymuş olmasına karşın bu makale, Puşkin'in şahsına ait kişisel sanat yetkinlikleri üzerinde değil, eserlerinde dile getirdiği okuyucuyu üzerinde düşünmeye sevk ettiği sanatsal yetkinlikler üzerinde durulmaktadır.

Aşağıdaki dizelerinde (ve genel anlamda eserlerinde) Puşkin, Rus ataerkil soylularının sanatsal alanlarda genel anlamdaki "yetkin olmayışlarını" fakat yetkin gibi görünmeye çalışan havai davranışlarını yermektedir. Kendilerini yetiştirme bakımından boş oluşlarını, yergisel betimlemelerle gözler önüne sermeye çalışmaktadır (Puşkin 2020, s. 18-19):

Yetersiz bilgiliydi, bilgiçti ama,

Konuşması sırasında hiç zorlanmadan

Her şeye değinmek gibi kolaylıkla

Takınmak bir allamenin bilginliğini,

Korumak bir tartışmada suskunluğunu

Ve beklenmedik epigramların alazıla

Ateşlemek gibi gülümsemesini hanımların

Pek uğurlu yetenekleri vardl.

Sanatsal yetkinliklere giriş niteliği taşıyan yukarıdaki anlatımların ardından aşağıdaki alt başlıklarda, Puşkin'in şair yönü ön plana çıkmış olmasından dolayı öncelikle şiir sanatı alanında sahip olunan bireysel yetkinlik konusu, daha sonra ise diğer sanat dalları alanında bireysel düzeyde sahip olunan yetkinlikler hususundaki görüşlerine yer verilmiştir.

\subsection{Puşkin'in şiir yetkinliğine ilişkin görüşleri}

Puşkin, 1928 Seferi Sirasında Erzurum'a Yolculuk başlıklı romanında, bir Türk paşasının şairlere özgü yetkinlikler konusundaki görüşlerine yer vermektedir. Puşkin ile olan görüşmesinde Türk paşası, şu sözleri dile getirmektedir (Puşkin, 2020a, s. 548): "Bir şairle karşılaşmak her zaman hayırlıdır. Şair, dervişin kardeşidir. Onun ne vatanı vardır, ne de dünya nimetlerinde gözü, Biz zavallılar şan, iktidar ve para peşinde koşarken, o, yeryüzünün hükümdarlarıyla aynı sırada durur ve herkes onun karşısında saygıyla eğilir.” Burada paşa, şair kişilerin evrensel niteliklerini öne çıkarmakta ve bunu övmektedir. Puşkin ile aynı ortamı paylaşan diğer bireyler de paşanın görüşünü onaylamaktadır. Türk paşasının yukarıda aktarılan sözleri, Puşkin (2020a, s. 548) tarafindan doğrudan doğruya benimsenmektedir. Zira Puşkin'in "Paşanın tam bir Doğulu olarak söylediği sözler hepimizin hoşuna gitti” şeklindeki ifadesi, Türk paşasının görüşlerine olumlu bir biçimde yaklaştığını göstermektedir.

Puşkin (2020a, s. 511), aynı eserinde, İranlı saray şairi Fazıl Han ile olan karşılaşmasını ise şu sözlerle ifade etmektedir:

Kafile subayı, İranlı saray şairini gördüğünü söyledi ve isteğim üzerine beni Fazıl Han'la tanıştırdı. Çevirmen yardımıyla, tumturaklı bir doğulu tavrıyla söze başlamıştım ki Fazıl Han benim saçma sapan sözlerime akıllı uslu karşılıklar verince ne kadar utandım! Beni Petersburg'da yeniden göreceğini umuyor, görüşmemizin kısalığından hayıflanıyordu. Kızarıp bozardım. Şakacıtumturaklı konuşma tarzını bırakarak normal bir batılı gibi konuşmak zorunda kaldım. Böylece de, biz Ruslara özgü o alaycılığın cezasını çekmiş oldum. Bundan böyle insanları kafalarındaki papağa ya da tırnaklarındaki kınaya bakarak yargılamayacağım.

Rus düşünür ve edebiyat eleştirmeni Belinski'nin de vurguladığı gibi, Puşkin'in erken dönem eserlerinden itibaren Rus yazın tarihinde yeni bir dönem başlamış, Puşkin'in eserleri, klasik akıma karşı kazanılan bir zafer olarak kabul edilmiştir. Puşkin'in öğretmeni Vasili Jukovski, Puşkin'e gönderdiği portresinin arkasına şöyle yazmıştır: "Kaybeden öğretmenden, zaferi kazanan öğrencisine..." (Yükseler, s. 2017: 8). Nitekim Ruslan ve Ludmila adlı eserinde Puşkin (2017, s. 61), Rus şairi Jukovski'yi, antik 
Yunan ozanlarından olan Orpheus'a benzetirken aynı zamanda şiir sanatına yönelik görüşlerini şu dizelerle ifade etmektedir:

Şiirin olağanüstü dehasl,

Gizemli imgelerin ozanı,

Aşkın, hayallerin ve iblislerin,

Cinlerin ve cennetin sadık sakini

Ve uçarl esin perimin

Sirdaşı, koruyucusu ve eğitmeni!

Bă̆ışla beni Orpheus'u kuzeyin,

Bu eğlenceli hikâyemde

Şimdi peşinden uçup gittiğim

Ve kaprisli esin perimin lirini de

Bu güzel yalanla açı̆̆a vurduğum için.

Aynı esrinde Puşkin (2017, s. 64), bir diğer antik Yunan ozanı olan Homeros'un şiir yeteneğini şu dizelerle dile getirmektedir:

...Homeros değilim ben; yüce şiirlerde

O terennüm edebilir sadece

Yunan birliklerin öğlen yemeklerini,

Ve derin çanakların köpü̈̆̈̈nü ve sesini...

Puşkin'in (2012, s. 143) Poltava adlı şiiri, şairleri etkileyen esin duygusunu anlatan aşağıdaki ithaf ile başlamaktadır:

Kasvetli esin perimin sesi sana,

Hiç değilse kulağına dokunur mu?

Anlayabilir misin uysal bir ruhla

Yüreğimdeki ateşli arzuyu?

Şairin bu ithafi yoksa,

Bir zamanlarin sevdasi gibi,

Yanitsiz ve kabul görmeden mi

Geçecek önünden bir kez daha?

Puşkin (2012, s. 213), Kolomna'daki Küçük Ev başlıklı şiirinde şiir yazma anlayışına ilişkin görüşlerini şu dizelerle dile getirmektedir:

Dört duraklı vezinden artık usandım:

Bunu herkes kullaniyor. Bırakmanin vakti geldi...

Zaten benimle teklifsizce yaşar uyaklar;

İkisi kendiliğinden gelir, üçüncüyü doğurur.

Puşkin (2012, s. 213), şiirdeki anlatı sanatı bakımından uyakları yapılandırırken fiil kullanımının, daha yalın bir biçim ortaya koyduğu görüşünü savunmakta ve bu yenilikçi görüşlerini şu dizelerle ifade etmektedir: 
Genellikle ben böyle yazarım

Niye? Söyleyin; bizler çıplağız gerçekte.

Uyaklarda fiil kullanacă̆ım bundan böyle.

Kibirlenip çürüğe çıkarmam onları ben,

A ğır yara almış acemi erler gibi öyle

Bu şiirinin devamında Puşkin (2012, s. 213-214), şairi, kelimeleri maharetle düzene sokan, belirli bir disiplin altına alan büyük ordu komutanları olan Timur ve Napolyon'a benzetmektedir.

"Ey Esin Perisi Ateşli Yerginin...” başlıklı şiirinde Puşkin (2020c, s. 49), ruhsuz öykünmeciler, aç çevirmenler, sorumsuz uyakçılar, mutsuz ozanlar ve gazete yardakçıları olarak nitelendirdiği belirli bir grup şairi, söz konusu nitelemeleriyle aslında şairlik için gerekli yetkinliklere haiz olmadıklarını yergi aracılığıyla ifade etmektedir. "Şair" başlıklı şiirinde ise şairde bulunan fakat avamda bulunmayan nitelikleri sıralamaktadır. Sıraladığı özellikleri, şairin üstün yönü olarak belirtmektedir. Puşkin, şairlerin lehine olarak tarif ettiği söz konusu belirgin asimetri nedeniyle şairlerin gururlu/mağrur kişiler olduğunu vurgulamaktadır (Puşkin, 2020c, s. 66). "Şaire" başlıklı şiirinde de benzer görüşlere yer vermekte hatta megalomanlığı çağrıştıracak düzeydeki bir kendini beğenmeyi ve her türlü eleştiriye karşı kayıtsız kalmayı, aşağıdaki dizelerle salık vermektedir (Puşkin, ty, s. 3):

Ey şair, kulak asma sevgisine sen halkın

O canım methüsena, anlık gürültü geçer;

Kuru kalabalığın gülüşünü duyarsın,

Ve aptalın hükmünü; fakat metin ol boş ver.

... Her şey sendedir, sende; büyük mahkeme sensin;

Eserine, elden çok, klymet biçebilensin,

Söyle ey titiz şair, sen ondan memnun musun?

Memnunsan, kalabalık varsin küfretsin sana...

Puşkin'in Onegin adlı anlatım kahramanı, gerçek bir ilgi ile yaklaşmadığı ve gerçek bir sevgi hissetmediği hâlde, sırf can sıkıntısından dolayı, yakın arkadaşı Lenski'nin eşinden hoşlanıyormuş gibi davranmakta, Lenski de onu düelloya davet etmektedir. Düello, şair olan Lenski'nin ölümüyle sonuçlanmaktadır (Puşkin, 2020b, s. 294). Edebiyatta "gereksiz insan tipi"nin ilk örneklerinden kabul edilen Onegin, kendisi sanatsal bir yeteneğe sahip bulunmadığ gibi, bir anda ve sebepsiz yere şairlik yeteneğine sahip Lenski'nin katiline dönüşmektedir.

Yukarıda kısaca betimlenen Onegin karakterinden yola çıkılıp çıkılmadığı kesin olarak bilinmemekle birlikle, Puşkin'in yaşamı da Lenski ile benzer bir biçimde sonlanmıştır. Zira Çarlık yönetimine muhalif görüşleri nedeniyle, Çarlık muhafız alayının en keskin nişancılarından D'Anthes, özel yaşamı ile ilgili olarak Puşkin'e karşı kışkırtıcı davranışlar sergilemeye başlamıştır. Bilinçli bir biçimde üzerine gidildiği takdirde duygularına hâkim olamayacağı öngörülen Puşkin, beklendiği üzere, rasyonel olmayan bir biçimde D'Anthes'i düelloya davet etmiştir (Bulgakov, 2012, s. 55). D'Anthes'i yaralayan Puşkin, kendisi de yara almış fakat bilgisiz ve ehliyetsiz doktorların müdahalesiyle adeta önceden düşünülerek ve planlanarak ölüme mahkûm edilmiştir (Bulgakov, 2012, s. 87-90). Benzer bir son, şairin ölümünden kısa bir süre sonra, Çarlık rejimi karşıtı, Puşkin ile yakın görüşlere sahip, bir diğer şair Lermontov'un da başına gelmiştir. Lermontov'un (2000, s. 32-34), Puşkin'in ölümü üzerine kaleme aldığ "Şairin Ölümü" adlı şiiri, Petersburg başta olmak üzere Rusya'nın birçok yerinde derin bir yankı uyandırmıştır. Lermontov'un şiiri, Petersburg'da dilden dile dolaşmaya başlayınca kent yöneticileri bu durumdan endişe duyarak çarlık rejimine ihbarda bulunmuş, Lermontov ise sürgüne gönderilmiştir. Puşkin'in üstadı Jukovsky, onun ölümü hakkında "Rus şiirinin güneşi battı" demiştir (Miziev ve Necdet, 2003, s. viii). Sonuç olarak, şair olan anlatım kahramanı Lenski ile gerçek birer kişilik olan Puşkin ve Lermontov'un sıralı ölümleri, çeşitli şüphelere neden olmuştur. "Her kuş kendi kanadından vurulur" 
söylemiyle örtüşen bir kurgu gibi gözüken bu durum (sanatsal yetkinliklere sahip bu tanınmış şahsiyetlerin şaibeli ölümleri) günümüzde de tam olarak aydınlatılabilmiş değildir. Gasset $(2018$, s. 96), sanatsal yetkinliğe sahip kişilere yönelen olumsuzlukları şu sözlerle ifade etmektedir: "Yücelik taşkınlığı, nitelik fazlalığı, başkaları gibi 'alelade' olmama iddiası taşımayan kimseye eyvahlar olsun! Reformcu, yeni sanat, yeni bilim, yeni politika gibi şeyler deneyen kişi, yaşadığ 1 sürece, onu sahtekâr değilse de mağrur addeden düşmanca, yıpratıcı bir camiadan geçer."

Mısır Geceleri öyküsünün Çarski adlı karakteri, şiir yazmak ve bunları yayınlamak mutsuzluğuna uğramış biri olarak betimlenmektedir. Şairlik damgasını bir kez yiyen kişinin yaşamı boyunca karşılaşabileceği çeşitli sorunların sıralandığı öyküde Çarski, şairliğin beraberinde getirdiği unvanlardan kurtulabilmek için yoğun bir çaba harcamaktadır. Edebiyat toplantılarından köşe bucak kaçmakta, en boş kafalılarla arkadaşlık kurmakta, "edebiyat" sözünü ağzına bile almamaktadır (Puşkin, 2020a, s. 336). Çarski'nin bu tavrı, dar bir mesleki jargon çerçevesinde kurulan ilişkilerden duyulan bıkkınlığı yansıtmaktadır. Tıpkı asker kişilerin yaptığı ve "postal sohbeti" olarak ifade edilen kasvetli ve usanç verici mesleki içerikli konuşmalara benzer bir biçimde Çarski karakteri de şairlik yeteneğinin doğal bir sonucu olarak ortaya çıkan şairlere özgü sohbetlerden usanmış ve giderek bu ortamlardan yabancılaşmıştır.

"Bülbül ve Gül” adlı şiirinde Puşkin (2003, s. 49), Doğu şiirinin başlıca sembollerinden olan "gül” ögesine, şair kişinin şiirsel yetkinliğini harekete geçirmesi yönüyle değinmektedir. Söz konusu değinmesiyle, gül imgesinin, şiirsel yetkinlikler açısından gerçekten de anlamlı bir katkı sağlayıp sağlamadığı (herhangi bir katalizör etkisi gösterip gösteremeyeceği) hususunu tartışmalı bir durum olarak değerlendirmektedir.

Puşkin'in, şiir sanatının dünyadaki yeri ve yükümlülükleriyle ilgili görüşleri, "Bir Kitap Satıcısının Şairle Konuşması" adlı şiirinde yer almaktadır. Felsefi bir düşünceyle son bulan bu şiirde Puşkin, kendisini şairin maskesi altına gizlememekte ve kitap satıcısının söylediklerine de tam olarak karşı çıkmamaktadır. Zamanın eğilimini de yansıtan bu konuşma, sorunun uygulama yönüne değinmektedir: "Şimdi sorun para" ifadesinde, hem kitap satıcısı, hem de şair kendi açılarından haklı yönlere sahip olarak betimlenmektedir. Zira yaşamın genel kanunlarının, şiirin "kutsal" olarak görülen alanına da sirayet etmekte olduğu ima edilmektedir. Sonuç olarak dile getirilen ifadelerde kitap satıcısı, şairin kendi kendisine duyduğu sevgiye acımak için yeterince akla sahip bulunmakta, şair ise küçültücü pazarlıktan ilhamla kendisini kurtarabilmek için daha az zekâya sahip bulunmamaktadır (Kuleşov, 2018, s. 201-202).

\subsection{Puşkin’in şiir haricindeki diğer anlatı sanatlarına ilişkin görüşleri}

Puşkin, Mozart ve Salieri adlı tragedyasında Mozart'ın sanatsal yeteneği üzerinde durmaktadır. Bu tragedyada Mozart, görme engelli bir meyhanecinin, kendi müzik eserlerini seslendirdiğini görünce onu alıp, arkadaşı olan İtalyan müzisyen Saileri’ye getirerek dinlettirmektedir. Salieri'nin fikrini soran Mozart, şu karşılığ almaktadır (Puşkin, 2019a, s. 27-28):

\section{Berbat bir ressam bana Rafael'in}

“Madonna"sinı çizmeye kalksa ona gülmem;

Bir şarlatan bana Alighieri'yi aşağılayıcı

Bir parodiyle taklide kalkışsa ona da gülmem...

Bana bunu getirirken,

\section{Yolda meyhanenin önünde durup kaldın}

Ve senin o kör kemancıy dikkatle dinledin ha! Tanrım!

Sen, Mozart, sen gerçekten kendine yakışıyorsun

Yukardaki sözleriyle Salieri, müzikal yetkinlik olarak üstün bir seviyede bulunan Mozart'in, görme engelli bir meyhanecinin seslendirdiği müziği dikkate almasını ona yakıştıramamaktadır. Salieri, aynı zamanda Mozart'ın doğuştan gelen müzikal yetkinliğine karşı acı verici derin bir kıskançlık duyduğunu şu sözleriyle dile getirmektedir (Puşkin, 2019a: 26): 
... Ah Tanrım!

Senin kutsal koruyuculuğun, sonsuz yaratıcılı̆̆ın

İç ısıtan sevginin, yaratıcı emeğin, çabanın, duanın

Ödülü olamaz da, ilgisiz, derbeder bir aptalın

Kafasında cılız bir parıltı olarak yer almışsa,

Bu, haksızlık olmaz mı?

Kendisi de değerli bir müzisyen olmasına karşın Salieri, Mozart'ın müzik alanında sahip olduğu yetkinlik asimetrisi, onu yakından tanıyan çevrelerde kıskançlığa neden olmaktadır. Bu kıskançlık ise piyasa işleyişi ya da doğal yaşamdaki "rekabet" olgusuna benzer bir biçimde, asimetrinin güçlü kısmında yer alan tarafı mutlak bir yenilgiye uğratma, bu uğurda gerekirse karşı tarafın yaşamına son verme düşüncesine de kaynaklık etmektedir. Nitekim söz konusu türden ağır duygular altında adeta ezildiğini hisseden Salieri, Mozart'in içeceğine zehir koyarak onu öldürmeye karar vermektedir. Salieri, yetenek fazlasının neden olduğu çekememezlik duygusunu ön plana çıkaran ve sanatsal yetkinliğe sahip bireyler arasındaki olumsuz nitelikteki "rekabet" anlayışını şu sözleri dile getirmektedir (Puşkin, 2019a, s. 29):

\section{Onun ilerleyişini frenlemek zorundayım}

Yoksa biz hepimiz her şeyi kaybedeceğiz.

Bütün üstatlar, bütün müzik emekçileri,

Yalnız donuk şöhretimle ben değil, hepimiz yok olacă̆ız.

Peki, bize ne faydası olacak, Mozart daha yaşarsa

Ve sürekli yükseklere tırmanmayı sürdürürse?

Bu şekilde müzik sanatını da mı yükseltmiş olacak? Hayır!

O ölüp kaybolduğu anda, sanat derhal düşüşe geçecek.

Goryuhino Köyü Tarihi adlı öyküsündeki anlatıcı karakteri, çocukluğundan itibaren edebiyat alanında eserler vermek istemektedir. Piyade alayında subay olan anlatıcı, anne ve babasının ölümü nedeniyle görevinden ayrılarak ata yurdu olan köyüne yerleşmektedir (Puşkin, 2020a: 157-158). Anlatıcı; şiir, trajedi, balat, hikâye ve diğer düz yazı türlerini deneyerek temel yetkinliğinin hangisinde olduğunu belirlemeye çalışmaktadır (Puşkin, 2020a, s. 163). Öykünün ilerleyen bölümlerinde anlatıcı, kendi yetkinliğine en uygun anlatı biçiminin, yerel tarih yazarlı̆̆g/araştırmacılığ olduğuna kanaat getirmektedir.

İktidar ile halk arasındaki ilişkileri ele alarak siyasi ve ahlaki konuları gündeme getirdiği Boris Godunov adlı tragedyasında Puşkin (2019b: 21), eserin içeriği gereği sanatsal yetkinlikler üzerinde durmamıştır. Buna karşın, Başrahip ve Patrik karakterleri arasında geçen diyaloglarda, dini ağıtlar yazmak da bir tür yazınsal yetkinlik olduğu için, okuyarak genel kültür sahibi olma, dini ve tarihi bilgilerle kendini yetiştirmenin önemine değinilmektedir. Yazınsal yetkinliği geliştirmeye dönük böylesi bir çabanın, Tanrı vergisi olarak vurgulanan yazma eylemine olumlu katkılar sağladığı belirtilmektedir.

\section{Sonuç}

Yetkinlik arayışı, hemen hemen bütün yaşamsal alanları kapsamış bulunmaktadır. Çalışma yaşamında (yetkinlik bazlı personel seçme ve yerleştirme, iş analizi, performans değerlendirme, ücret yönetimi kariyer planlama), kurum ve kuruluşlardaki başarı kriterlerinin dayandırıldığı mükemmeliyet modellerinde (EFQM: European Foundation for Quality Management; Altı Sigma: Üretim hatalarını milyonda birin altına indirmeyi amaçlayan mükemmel bir biçimde kurgulanmış üretim sistemi) ve yönetim teorileri (Chris Argyris'in olgunlaşma kuramı) gibi birçok farklı disiplinde yetkinlik vurgusu ön plana çıkarılmaktadır. Bilimde, performans sporlarında ve daha birçok alanda yetkinlik arayışı süregelmektedir. Hatta tasavvuf alanında yüzyıllardır yazılı eserlere konu edilen (zahid, abid ve arif 
gibi) manevi makamların da, sahip olunan kişisel yetkinlikler bağlamında açıklanmakta olduğu görülebilmektedir. Daha da geriye gidildiğinde ise çoğu toplumda görülen "altın çağ" söylenceleri de yetkinlik arayışının mitolojik kökenine işaret etmektedir.

Yukarıdaki örneklerden de anlaşılabileceği üzere, yetkinlik/mükemmellik arayışı, bu makalede sıralanamayacak kadar çok ve farklı sahalarda uygulama alanı bulabilmektedir. Bu makale, söz konusu geniş açılımın "sanatsal" alan ile ilgili olanına, bunun da özelinde, Puşkin'in sanatsal yetkinliğe ilişkin yaklaşımına odaklanmıştır. Bu odaklanmaya rağmen yine de tanınmış düşünür ya da yazarların eserleri hakkında görüş öne sürerken ihtiyatlı olmayı elden bırakmamak gerekmektedir. Bu nedenle makalede mutlak bir hüküm verici tavırdan kaçınmaya özen gösterilmiştir. Zaten belirli bir yapıt ya da yapıtlar grubu ele alınırken, odaklanılan hususlar, diğer birtakım nitelikleri kaçınılmaz olarak arka plana almayı zorunlu kılmaktadır. Makalede, Puşkin'in poetik ve diğer sanatsal (anlatı) yetkinliklere ilişkin görüşlerini ön plana çıkarırken, eserlerindeki başka niteliklere değinilmemiştir.

Comte (2015, s. 33-34), Batı Katolizminin dogma ve kültünün içerimlerini eleştiriye tabi tutmaktadır. Orta Çağ İslam anlayışının karakteristik bir yalınlıkla benimsediği sosyokratik (bilim ve sanat egemenliği) anlayışını, Katolizmin tam karşısına koyarak spekülatif, teorik ve estetik kültürün (mimari ve astronomi başta olmak üzere) sergilediği gelişimi izah etmektedir. Batılı bir düşünür, üstelik pozitivizmin kurucusu Comte'dan aktarılan yukarıdaki görüşlere, sanatın, Doğu-Batı ayrımı olmaksızın bütün kadim kültürlerde kendine yer edinebildiğini vurgulamaktadır. "Her ülkede sanat vardı" diyen Valery (1996: 60) de Comte'un kadim kültürlerdeki sanatın kökenlerine işaret etmektedir. Nitekim Puşkin de sanatın yalnızca Batı'ya (Batı Avrupa) özgü bir nitelik olduğu görüşüne kendini kaptırmış görünen yüksek Rus sosyetesini eleştirmiş, Rus toplumunun da (doğal olarak) diğer toplumlar kadar sanatsal yeteneğe sahip olduğunu, bunu da pekâlâ yetkinliğe dönüştürebileceğini belirterek kendi toplumuna güven aş1lamaya gayret etmiştir.

Romantizmin öncülerinden olan İngiliz şair Byron'dan etkilenen Puşkin, anlatımlarının merkezindeki kahramanın iç dünyası ve ruhsal çatışmaları etrafında eserlerini kurgulamıştır. Puşkin'in eserlerindeki kahramanın duyguları, olayların önüne geçmekte ve şairin kendi iç dünyasını ifade etmesinin bir aracı hâline gelmektedir (Ağaoğlu, 2018, s. 14). Dolayısıyla konuya bu makale özelinde bakıldığında, Puşkin'in eserlerindeki bütün anlatımların (kahramanlar aracılığıyla aktarılanlar da dâhil olmak üzere), Puşkin'in sanatsal yetkinliklere ilişkin kendi görüşleri olduğu çıkarsaması kendiliğinden ortaya çıkmaktadır. Puşkin $(2012$, s. 216) anlatı sanatlarında yetkinlik sahibi olan bireylere ilişkin görüşünü şu sözleriyle özgün bir biçimde ifade etmektedir: "Mutludur, söze sağlamca hükmedebilen ve düşüncesinin dizginlerini elinde tutan." Sonuç olarak, sanatın yer edinebilmesi için gerek duyulan ve yeteneğin yanı sıra özverili bir çalışmayı da gerektiren sanatsal yetkinliklerin ifade ettiği değerin farkına varmış biri olarak Puşkin hem ülkesine hem de tüm insanlığa bu alanda kişisel düzeyde elinden gelen katkıları sağlamaya çalışmıştır. 


\section{KAYNAKÇA}

Ağaoğlu, A. (2018). Bahçesaray çeşmesi. A. S. Puşkin (Çev. A. Ağaoğlu), Önsöz (ss.7-78) içinde. Ötüken Neşriyat.

Alighieri, D. (2020). Yeni hayat. (Çev. I. Saatçıŏlu). Yapı Kredi Yayınları.

Aristoteles. (2019). Ruh üzerine. (Çev. L. L. Basut \& S. Babür). BilgeSu Yayıncılık.

Bakkal, R. (1998). Tanıtamadığımız Yahya Kemal. Avrasya Bir Vakfı Yayınları.

Balzac, H. De. (2020). Lanetli çocuk. (Çev. O. Türkay). Yapı Kredi Yayınları.

Barney, J. (1991). Firm resources and sustained competitive advantage. Journal of Management, 17(1), 99-120.

Behramoğlu, A. (2013). Rus edebiyatında Puşkin gerçekçiliği. Tekin Yayınevi.

Behramoğlu, A. (2020). A. S. Puşkin. Yüzbaşının kızı -bütün öyküler bütün romanlar-. (Çev. A. Behramoğlu), Öykü ve Roman Yazarı Olarak Aleksandr Puşkin (ss. vii-xi) içinde. Türkiye İş Bankası Kültür Yayınları.

Bruno, G. (2020). Küllerin şöleni. (Çev. H. Portakal). Cem Yayınevi.

Bulgakov, M. (2012). Son günler (Aleksandr Puşkin). (Çev. M. Beyhan). Everest Yayınları.

Burke, E. (2008). Yüce ve güzel kavramlarımızın kaynağı hakkında felsefi bir soruşturma. (Çev. M. B. Gümüşbaş). BilgeSu Yayıncılık.

Butler, E. (2018). Kısaltılmış milletlerin zenginliği ve epey kısaltılmış ahlaki duygular kuramı. (Çev. H. Şahin). Librete Yayınları.

Cahiz, Ebu Osman (2019). Ahlak ve eğitimi. (Çev. E. Urcan). Veciz Yayınları.

Cahiz, (2020). Giysiler, kitaplar, öğretmenler ve şarkıcı kızlar kitabı. (Çev. M. H. Özev). Karbon Kitaplar.

Collingwood, R. G. (2019). Kısaca sanat felsefesi. (Çev. T. Kabadayı). BilgeSu Yayıncılık.

Comte, A. (2015). İslamiyet ve pozitivizm. (Çev. Ö. Gözel). Dergah Yayınları.

Çıkla, S. (2008, 3-7 Kasım). Yahya Kemal’in şöhreti ve mükemmeliyet anlayışı. [Konferans sunumu]. Bir Medeniyeti Yorumlamak Ölümünün 50. Yılında Yahya Kemal Beyatlı Sempozyumu, 125133.

Doğan, M. C. (2011). Mükemmeliyetçiliğin yarım bıraktı̆̆g şiirler. Gazi Türkiyat Araştırmaları Dergisi, 9, 101-113.

Dostoyevski, F. M. (1973). Ob iskusstve (İzdatelstvo “ískusstvo”). Moskova.

Dostoyevski, F. M. (2019). Puşkin üzerine üç konuşma (batı çıkmazı). (Çev. G. Şahin). Karbon Kitap.

Durukoğlu, S., \& Toprak, A. S. (2019). Şiirde biçim bağlamında yenilik- mükemmellik arayışları ve parnasizmin kısa tarihi. AKRA Kültür Sanat ve Edebiyat Dergisi, 7(17), 47-59.

Ersoy, C. (2010). A.S. Puşkin ve masalları, [Yayımlanmış yüksek lisans tezi], İstanbul Üniversitesi.

Gasset, J. O. Y (2018). Quijote üzerine düşünceler. (Çev. M. S. Şener). Yapı Kredi Yayınları.

Gazzali, (2020). Filozofların tutarsızlı̆̆ı. (Çev. M. Kaya \& H. Sarığlu). Klasik Yayınları.

Gorki, M. (2020). Tolstoy'dan anılar. (Çev. A. Göktürk). Yapı Kredi Yayınları.

Gürbüz, S. ve Şahin, F. (2018). Sosyal bilimlerde araştırma yöntemleri felsefe-yöntem-analiz. Seçkin Yayıncilik.

Habermas, J. (2019). “İdeoloji” olarak teknik ve bilim. Çev. (M. Tüzel). Yapı Kredi Yayınları. 
Kayseri Üniversitesi Sosyal Bilimler Dergisi, Cilt 2, Sayı: 2, Aralık 2020, 98-113

Kayseri University Journal of Social Sciences, Vol 2, No: 2, December 2020, 98-113

Hamel, G. ve Prahalad, C. K. (1996). Geleceği kazanmak. (Çev. Z. Dicleli). İnkılap Kitabevi.

Hariri, (2012). Makamat. (Çev. S. Sevsevil). Kabalcı Yayıncılık.

Hegel, G. W. F. (2011). Doğa Felsefesi-I Mekanik. (Çev. A. Yardımlı). İdea Yayınevi.

Horatius, (2019). Ars poetica -şiir sanatı-. (Çev. C. C. Çevik). Türkiye İş Bankası Kültür Yayınları.

Husserl, E. (2017). Fonomenoloji üzerine beş ders. (Çev. H. Tepe). BilgeSu Yayıncılık.

Husserl, E. (2020). Kesin bilim olarak felsefe. (Çev. T. Mengüşoğlu). Yapı Kredi Yayınları.

Kuleşov, V. İ. (2018). Puşkin yaşamı ve sanatı. (Çev. B. Karaca). Cümle Yayınları.

Lermontov, M. (2000). Şairin ölümü. (Çev. K. Miziev \& A. Necdet). Broy Yayınevi.

Lessing, G. E. (2019). Düzyazı fabllar. (Çev. Z. A. Yılmazer). Türkiye İş Bankası Kültür Yayınları.

Lessing, G. E. (2020). Minna von barhelm yahut asker saadeti. (Çev. S. Ali). Karbon Kitaplar.

Levy, C. (2016). Kuşkuculuk. (Çev. I. Ergüden). Dost Kitabevi.

Maga, İ. (2003). Çar sultan. (Çev. Ö. Asiltürk). Son söz: Puşkin'in masal yolu (ss. 45-51) içinde. YazıGörüntü-Ses Yayınları.

Miziev, K., \& A. Necdet (2003) "Sunuş”, A. S. Puşkin, aşk şiirleri (Çev. K. Miziev \& A. Necdet) Sunuş (ss. v-viii) içinde. Everest Yayınları.

Mengüşoğlu, Tomris (2020). E. Husserl, Kesin bilim olarak felsefe (Çev. T. Mengüşoğlu) Önsöz (ss. 934) içinde. Yapı Kredi Yayınları.

Mettrie, J. O. (1985). Insan bir makine. (Çev. Z. Bayramoğlu). Süreç Yayıncılık.

Novalis, F. L. F. von H. (2003). Poetika. (Çev. A. Sarı \& Ş. Çoraklı). Babil Yayınları.

Puşkin, A. S. (2003). Aşk şiirleri. (Çev. K. Miziev \& A. Necdet). Everest Yayınları.

Puşkin, A. S. (2012). Poemalar. (Çev. K. Yükseler). Yapı Kredi Yayınları.

Puşkin, A. S. (2017). Ruslan ve Ludmila. (Çev. K. Yükseler). Yapı Kredi Yayınları.

Puşkin, A. S. (2018). Bahçesaray çeşmesi. (Çev. A. Ağaoğlu). Ötüken Neşriyat.

Puşkin, A. S. (2019a). Küçük tragedyalar. (Çev. T. Y. Öğüt). Mitos-Boyut Tiyatro Yayınları.

Puşkin, A. S. (2019b). Boris Godunov. (Çev. Ö. Özer). Türkiye İş Bankası Kültür Yayınları.

Puşkin, A. S. (2020a). Yüzbaşının kızı -bütün öyküler bütün romanlar-. (Çev. A. Behramoğlu). Türkiye İş Bankası Kültür Yayınları.

Puşkin, A. S. (2020b). Yevgeni onegin. (Çev. A. Yaran). Yapı Kredi Yayınları.

Puşkin, A. S. (2020c). Seviyordum sizi seçme şiirler. (Çev. A. Behramoğlu). Türkiye İş Bankası Kültür Yayınlar1.

Puşkin, A. S. (ty). Seviyordum sizi seçilmişş̧iirler. (Çev. A. Yaran, A. Behramoğlu, K. Miziev, A. Necdet, S. Aytekin, H. Madencioğlu). Simge Yayıncılık.

Razi, F. (2018). Arifler ve olağanüstü hadiselerin sırları. (Çev. Ö. Türker). Hayy Kitap.

Sutherland, J. (2018). Edebiyatın kısa tarihi. (Çev. T. Göbekçin). Alfa Basım Yayım.

Tevhidi, E. H. (2020). Akıl, ahlak, eylem ve ruh üzerine akşam sohbetleri. (Çev. M. H. Özev). Karbon Kitaplar.

Türk Dil Kurumu. (2011). Türkçe sözlük.

Valery, P. (1996). Tinsel kriz. (Çev. B. Beken). AFA Yayıncılık.

Manen, M. van (1990). Researching lived experience. State University of New York Press.

Vico, G. (2017). Çağımızın araştırma yöntemleri üzerine. (Çev. T. Kabadayı). BilgeSu Yayıncılık. 
White, S. K. (2013). Edmund Burke: modernite, politika ve estetik. (Çev. M. Şenses). Paradigma Yayıncilik.

Yükseler, K. (2017). A. S. Puşkin, Ruslan ve ludmila. (Çev. K. Yükseler). Çevirmenin önsözü (ss. 7-8) içinde. Yapı Kredi Yayınları. 